\title{
Effects of Sweet Potato Leaves, Roselle Calyces and Beetroot on Body Weight, Selected Hematological and Biochemical Parameters in Broiler Chicken
}

\author{
Gaymary George Bakari (Corresponding Author) \\ Department of Veterinary Physiology, Biochemistry and Pharmacology, P.O. Box 3017, \\ College of Veterinary and Biomedical Sciences, Sokoine University of Agriculture, Morogoro, \\ E mail: manemgay@yahoo.com; gaymary.bakari@ sua.ac.tz
}

\begin{abstract}
Robert Arsen Max
Department of Veterinary Physiology, Biochemistry and Pharmacology, P.O. Box 3017, College of Veterinary and Biomedical Sciences, Sokoine University of Agriculture, Morogoro,

Tanzania. Email: robertmax@sua.ac.tz

Shedrack Reuben Kitimu

Department of Veterinary Physiology, Biochemistry and Pharmacology, P.O. Box 3017, College of Veterinary and Biomedical Sciences, Sokoine University of Agriculture, Morogoro,

E mail: skitimu@sua.ac.tz
\end{abstract}

\section{Shaabani Mshamu}

Department of Veterinary Physiology, Biochemistry and Pharmacology, P.O. Box 3017, College of Veterinary and Biomedical Sciences, Sokoine University of Agriculture, Morogoro, E mail: bentemba@sua.ac.tz

Benigni Alfred Temba

Department of Veterinary Physiology, Biochemistry and Pharmacology, P.O. Box 3017, College of Veterinary and Biomedical Sciences, Sokoine University of Agriculture, Morogoro, E mail: bentemba@sua.ac.tz

Amandus P. Muhairwa

Department of Veterinary Medicine, P. O. Box 3021, College of Veterinary and Biomedical 
Sciences, Sokoine University of Agriculture, Morogoro, Tanzania, Email: apm@sua.ac.tz

Received: April 7, 2019 Accepted: July 1, 2019

doi:10.5296/jbls.v10i2.14620ＵRL: https://doi.org/10.5296/jbls.v10i2.14620

\begin{abstract}
The study was conducted to assess the effects of sweet potato leaves, roselle calyces and beetroot tubers on body weight, selected hematological and biochemical parameters in broiler chickens. Eighty four (84) broiler chickens aged four weeks were randomly assigned into six groups of 14 chickens each. The first group (G0) remained as untreated control while the other groups were the treated groups which received $25 \%$ of ground sweet potato leaves $(\mathrm{G} 1)$, rosella calyces (G2), beetroot tubers (G3) and their mixtures (G4 and G5) for 28 days. Following inclusion of these different vegetables, blood samples were collected and analyzed for selected hematological and biochemical parameters on day 0, 7, 14, 21 and 28. Results showed that consumption of the three vegetables caused significant decreases $(p<0.05)$ in body weight, serum glucose and cholesterol. On the other hand, hemoglobin concentration, packed cell volume (PCV) and total white blood cell (WBC) counts were shown to increase significantly ( $\mathrm{p}<0.05$ ) compared to the control group. It is concluded that the hypoglycemic and hypocholesteremic effects in chickens following consumption of the three vegetables together with their positive effects on PCV and WBC counts are important qualities which can be utilized in the management of conditions such as obesity, diabetes mellitus, hyperlipidemia and cardiovascular diseases (atherosclerosis and coronary disease) in humans. Further studies in other animals are recommended.
\end{abstract}

Keyword: sweet potato leaves, roselle calyces, beetroot tubers, hypoglycaemia, hypocholesteremia, packed cell volume, haemoglobin concentration

\title{
1. Introduction
}

Haematological and biochemical parameters are important tools in diagnosing the structural and functional status of the animal's body (Elagib and Ahmed, 2011). These parameters can be influenced by several factors including; nutritional factors (Etim et al., 2014), environmental factors (Vecerek et al., 2002); (Graczyk et al., 2003), diseases and age (Talebi et al., 2005). Various studies have been done on the effect of food supplements, different diets (nutrition), management system, sex and breed on hematological parameters of broiler chickens. Information on the use of plants as food supplements on animal and human health is scarce. However, there are important plants with nutritive importance which are yet to be studied and utilized (Antia et al., 2006). Plants such as sweet potatoes (Ipomea batata), roselle (Hibiscus sabdariffa), beetroot (Beta vulgaris) and burn (Aloe vera) among others have been used for decade and claimed to possess several effects on body weight and blood parameters. 
Sweet potato (Ipomoea batatas) is a herbaceous creeping plant with smooth, lightly moderate green leaves sometimes with a considerable amount of purple pigmentation especially along its veins (Scaramuzzi, 1986). While it is the second most important tuberous plant in tropical economies preceded by cassava, it is also the third in Sub-Saharan Africa after cassava (Manihot esculenta Crantz.) and yam (Dioscorea spp (L.). It is an important subsistence food crop grown in almost all agro-ecological zones for its storage roots, which are used for both human and animal consumption. Several reports have indicated that there are phytochemical constituents such as polyphenols and carotenoids which are very beneficial for human and animal health. Sweet potato leaves also are well known for their medicinal effect Mohanraj and Sivasankar, 2014. These medicinal properties of sweet potato include anti-cancer, anti-diabetic, anti-inflammatory, anti-oxidant, anti-bacterial, anti-fungal, anti-viral, anti-ulcer, hepatoprotective, wound healing, and immunomodulatory activities (Mohanraj and Sivasankar, 2014). Sweet potatoes can alleviate muscle cramps due to their high potassium content which are often related to potassium deficiency (Milind and Monica, 2015). Sweet potatoes leaves contain magnesium, a crucial mineral, which promotes relaxation, calmness and nerve health, also reported to be used in traditional medicine as a remedy for anaemia due to it haematinic effects (Osime et al., 2008).

Beetroot (Beta vulgaris) is a naturally occurring root vegetable that is commonly found in many countries worldwide, where it is consumed as part of the normal diet. In recent years, the beetroot vegetable has attracted much attention as a health promoting functional food (Ninfali and Angelino, 2013). The recent interest in beetroot is driven by discoveries including its importance in managing cardiovascular problems and as a sources of dietary nitrate (Lundberg et al., 2008). Beetroot is rich in several other bioactive compounds that may provide health benefits, particularly for disorders characterized by chronic inflammation and cancer (Lechner et al., 2010). Also, recent studies have provided compelling evidence that beetroot is used to improve clinical conditions in human beings such as hypertension, atherosclerosis, type 2 diabetes and dementia (Gilchrist et al., 2014). Studies on hypertension have shown that beetroot used as juice supplement (Jajja et al., 2014), or in bread (Hobbs et al., 2013), significantly reduce systolic and diastolic blood pressure (Lidder and Webb, 2013).

Roselle (Hibiscus sabdariffa) is an annual or perennial herb which is a good source of polyphenolic and flavonoid compounds (Wang et al., 2000). Roselle is reported to have hypotensive effects, decreasing the blood viscosity, body temperature and stimulating intestinal peristalsis (Hopkins et al., 2013; Onyenekwe et al, 1999). Other studies have reported that roselle can prevent diseases like hyperlipidemia and cardiovascular diseases (atherosclerosis and coronary heart disease (Chang et al., 2006; Farombi and Ige, 2007; Gosain et al., 2010; Ochani and D'Mello, 2009). The extracts were able to control blood cholesterol by lowering low-density lipoprotein cholesterol (LDL-c), triglycerides (TAG), total cholesterol (TC) and lipid peroxidation in vivo and able to reduce very-low density lipoprotein cholesterol along with an increase in serum level of high density lipoprotein cholesterol (HDL-c). Other reported medicinal effect of roselle include: antiseptic, diuretic, purgative, sedative and emollient (Nkumah, 2015).

The research to date has focused on the effects of these plants in rats and human beings and 


\section{Macrothink

there is no reliable evidence on their use in chickens. Furthermore, some of plant products are advocated as feed additives in chickens, including the plants in this study. Thus, it is worth determining their effects on different parameters in broiler chickens. Therefore, this work aimed at assessing the effects of the studied vegetables on body weight, hematological and biochemical parameters in broiler chickens.

\section{Methods and Methodology}

\subsection{Study Area}

This study was conducted at Sokoine University of Agriculture, Morogoro Municipal, Morogoro region, Tanzania. The chickens were raised at Animal Science farm. Animal experiments and sample processing were conducted at Department of Veterinary Physiology, College of Veterinary Medicine and Biomedical Science.

\subsection{Research Design}

Eighty four (84) broiler chickens of four weeks of age were sourced from farmers around Morogoro municipality. The chickens were left for three weeks to acclimatize with experimental environment. Following acclimatization, they were weighed, wing tagged and randomly assigned into six groups of 14 chickens each. The first group was the control (G0) while the rest of groups (G1, G2, G3, G4 and G5) were the experimental groups. Broiler chicken were then kept in different cages according to experimental groups and received different feed rations for 35 days as shown in table 1 below. All broiler chicken were fed with broiler mash and given water ad libitum.

Table 1. Grouping and feed ration allocation

\begin{tabular}{ll}
\hline Group $(\mathrm{n}=14)$ & Treatment \\
\hline G0 & No additional feed \\
G1 & Sweet potato leaves \\
G2 & Roselle calyces \\
G3 & Beetroot tuber \\
G4 & Beetroot and roselle \\
G5 & Sweet potato and roselle \\
\hline
\end{tabular}

\subsection{Preparation of Sweet Potato Leaf, Beetroot Tuber and Roselle Powder for Chicken Feed}

Fresh green potato leaves, beetroot tubers and dried roselle was purchased from local market in Morogoro region. The fresh potato leaves and beetroot tubers were chopped into small pieces and then shade dried for two weeks before the commencement of the experiment. Then 
$1000 \mathrm{~g}$ of the potato leaves, beetroot tubers and roselle calyces were ground to pass through $2 \mathrm{~mm}$ diameter sieve. The powder obtained was mixed with normal broiler mash to make $25 \%$ of the daily intake of the birds which ranged from 90 to130g per day.

\subsection{Body Weight and Sample Collection and Analysis}

Before collection of blood, body weights were measured on day 0, 7, 14, 21 and 28 using a weighing balance. Blood samples (approx. $3 \mathrm{~mL}$ ) were collected from wing veins using syringe with $23 \mathrm{G}$ needle at regular interval from day $0,7,14,21$ and 28 . About $1 \mathrm{~mL}$ blood was then transferred into sample bottles containing EDTA for hematological parameters analysis, while the remaining $2 \mathrm{~mL}$ were immediately centrifuged at $3000 \mathrm{rpm}$ for 10 minutes to obtain fresh plasma. The plasma was used for analysis of biochemical parameters using spectrophotometer (Cole Patner 1100 rs). All sampling was carried out in the morning between 7 a.m. and 9 a.m. in order to reduce diurnal variability which might affect the parameters.

\subsection{Determination Haematological Parameters}

Haematological parameters including packed cell volume (PCV), haemoglobin level $(\mathrm{Hb})$, red blood cell count (RBCs), white blood cell count (WBCs) and differential WBCs (lymphocytes, monocytes, heterophils and eosinophils) were analyzed using hematological analyzer machine (Mythic 18 Vet Haematology Analyser)

\subsection{Determination of Biochemical Parameters}

Determination of the blood glucose and plasma total cholesterol levels were done by the glucose-oxidase and the formation of cholesterol and fatty acids principles as explained by Trinders et al., 1969. Total protein was determined by Biuretic method using Erba ${ }^{\circledR}$ test kit as described by WHO, 2006.

\subsection{Statistical Analysis}

Means and standard deviation were determined using Excel statistical analysis. Comparisons between treated and treated groups were analyzed using student ANOVA Single Factor at 95\% confidence interval and 5\% level of significance.

\section{Results}

Following inclusion of the studied vegetables, no death or any sign of illness was observed throughout experiment time, rather there was increased in the amount of feed taken by each chicken which ranged from $90 \mathrm{gm}$ to $130 \mathrm{gm}$ per day.

Mean body weights of chickens in G0 and G1 increased gradually $(\mathrm{p}<0.001)$ throughout the experimental period compared to other experimental groups. From day 3 of treatment, the body weights of chickens in G2, G3, G4 and G5 decreased significantly in relation to the type of feed given to the chicken $(\mathrm{P}<0.01)$ as shown in table 2 below. The decreased body weight is marked on day 21 of the experiment. 


\section{Macrothink}

Table 2. Weight gain following inclusion of sweet potato leaves, roselle and beetroot in diet

Body weight (gm)/ Number of days on experiment

\begin{tabular}{lccccc}
\hline Group & $\mathbf{0}$ & $\mathbf{7}$ & $\mathbf{1 4}$ & $\mathbf{2 1}$ & $\mathbf{2 8}$ \\
\hline G0 & $392.9 \pm 50.6$ & $606.0 \pm 58.6$ & $771.0 \pm 86.2$ & $850.6 \pm 81.8$ & $1021.6 \pm 133.2$ \\
G1 & $451.9 \pm 97.0$ & $543.6 \pm 81.6$ & $694.9 \pm 85.6$ & $752.3 \pm 87.1$ & $785.1 \pm 90.4$ \\
G2 & $401.0 \pm 40.8$ & $452.0 \pm 27.6$ & $505.4 \pm 60.5$ & $470.7 \pm 21.0$ & $468.2 \pm 21.7$ \\
G3 & $430.0 \pm 26.4$ & $466.0 \pm 39.9$ & $467.0 \pm 45.7$ & $430.8 \pm 20.3$ & $426.2 \pm 13.0$ \\
G4 & $452.0 \pm 48.8$ & $465.7 \pm 63.5$ & $523.0 \pm 74.7$ & $419.3 \pm 35.7$ & $408.8 \pm 41.7$ \\
G5 & $561.3 \pm 83.1$ & $662.3 \pm 75.3$ & $687.7 \pm 58.8$ & $573.0 \pm 34.3$ & $494.7 \pm 34.5$ \\
\hline
\end{tabular}

Hematological parameters are presented in Table 3. PCV and $\mathrm{Hb}$ values of chickens in the control group (G0) were changing invariably with the slight increase from day 14 of experiment. The increased levels of PCV and Hb were significantly higher $(p=0.007)$ in $\mathrm{G} 1$, G4 and G5. Total RBC and WBC count also were observed to increase $(p<0.05)$ in all experimental groups. 
Table 3. Hematological parameter following inclusion of selected vegetables

\begin{tabular}{|c|c|c|c|c|c|c|}
\hline \multirow[b]{2}{*}{ Parameters } & \multicolumn{6}{|c|}{ Number of days on experiment } \\
\hline & Group & 0 & 7 & 14 & 21 & 28 \\
\hline \multirow[t]{6}{*}{$\operatorname{PCV}(\%)$} & G0 & $19.7 \pm 1.0$ & $24.4 \pm 1.9$ & $26.2 \pm 1.3$ & $25.0 \pm 0.6$ & $25.6 \pm 1.8$ \\
\hline & G1 & $19.4 \pm 1.2$ & $23.8 \pm 1.1$ & $26.0 \pm 1.8$ & $25.6 \pm 1.4$ & $32.0 \pm 1.5$ \\
\hline & G2 & $18.0 \pm 0.6$ & $21.7 \pm 1.4$ & $25.3 \pm 0.7$ & $25.2 \pm 0.5$ & $25.8 \pm 1.2$ \\
\hline & G3 & $20.6 \pm 1.4$ & $26.7 \pm 0.9$ & $27.3 \pm 1.2$ & $27.1 \pm 1.0$ & $28.0 \pm 1.7$ \\
\hline & G4 & $18.7 \pm 1.4$ & $26.1 \pm 0.7$ & $28.4 \pm 1.1$ & $31.9 \pm 2.7$ & $32.4 \pm 0.9$ \\
\hline & G5 & $22.0 \pm 1.6$ & $24.3 \pm 0.5$ & $28.9 \pm 0.9$ & $30.9 \pm 1.6$ & $34.0 \pm 2.0$ \\
\hline \multirow[t]{6}{*}{$\mathrm{Hb}(\mathrm{g} / \mathrm{dL})$} & G0 & $9.4 \pm 0.4$ & $11.3 \pm 0.2$ & $10.8 \pm 0.6$ & $10.9 \pm 0.9$ & $10.7 \pm 0.5$ \\
\hline & G1 & $9.1 \pm 0.5$ & $10.1 \pm 0.4$ & $11.0 \pm 0.6$ & $12.4 \pm 1.2$ & $14.4 \pm 0.8$ \\
\hline & G2 & $9.5 \pm 0.8$ & $10.7 \pm 0.7$ & $10.7 \pm 0.6$ & $11.9 \pm 0.8$ & $12.7 \pm 0.7$ \\
\hline & G3 & $9.7 \pm 0.4$ & $10.8 \pm 0.4$ & $11.1 \pm 0.4$ & $12.2 \pm 0.9$ & $13.6 \pm 0.4$ \\
\hline & G4 & $10.2 \pm 0.5$ & $11.5 \pm 0.6$ & $12.2 \pm 0.4$ & $12.3 \pm 0.8$ & $13.2 \pm 0.4$ \\
\hline & G5 & $10.4 \pm 0.3$ & $11.1 \pm 0.3$ & $11.6 \pm 0.3$ & $12.2 \pm 0.2$ & $14.2 \pm 0.8$ \\
\hline \multirow[t]{6}{*}{$\operatorname{RBC}\left(\times 10^{6} \mu \mathrm{l}\right)$} & G0 & $1.5 \pm 0.2$ & $2.3 \pm 0.2$ & $1.8 \pm 0.5$ & $2.3 \pm 0.1$ & $2.3 \pm 0.1$ \\
\hline & G1 & $2.0 \pm 0.2$ & $1.5 \pm 0.3$ & $2.5 \pm 0.1$ & $2.4 \pm 0.1$ & $2.3 \pm 0.1$ \\
\hline & $\mathrm{G} 2$ & $1.3 \pm 0.1$ & $2.0 \pm 0.4$ & $2.1 \pm 0.2$ & $2.4 \pm 0.1$ & $2.7 \pm 0.2$ \\
\hline & G3 & $1.4 \pm 0.2$ & $2.4 \pm 0.1$ & $2.6 \pm 0.2$ & $2.8 \pm 0.3$ & $2.9 \pm 0.2$ \\
\hline & G4 & $1.5 \pm 0.9$ & $1.3 \pm 0.2$ & $1.5 \pm 0.1$ & $2.0 \pm 0.2$ & $2.6 \pm 0.0$ \\
\hline & G5 & $1.8 \pm 0.3$ & $2.3 \pm 0.1$ & $2.2 \pm 0.1$ & $2.3 \pm 0.1$ & $2.5 \pm 0.1$ \\
\hline \multirow[t]{6}{*}{$\mathrm{WBC}\left(\times 10^{3} \mu \mathrm{l}\right)$} & G0 & $1.0 \pm 0.1$ & $1.6 \pm 0.1$ & $1.5 \pm 0.4$ & $1.4 \pm 0.3$ & $2.0 \pm 0.2$ \\
\hline & G1 & $2.1 \pm 0.2$ & $2.0 \pm 0.2$ & $2.1 \pm 0.3$ & $2.4 \pm 0.3$ & $2.0 \pm 0.8$ \\
\hline & G2 & $1.1 \pm 0.4$ & $2.4 \pm 0.1$ & $2.5 \pm 0.5$ & $2.6 \pm 0.5$ & $2.9 \pm 1.5$ \\
\hline & G3 & $1.0 \pm 1.1$ & $1.4 \pm 1.5$ & $1.3 \pm 0.6$ & $1.3 \pm 1.0$ & $2.9 \pm 1.5$ \\
\hline & G4 & $1.1 \pm 0.1$ & $1.3 \pm 0.6$ & $1.9 \pm 0.1$ & $2.8 \pm 0.2$ & $4.9 \pm 0.3$ \\
\hline & G5 & $2.2 \pm 0.2$ & $1.6 \pm 0.9$ & $3.1 \pm 0.2$ & $1.0 \pm 0.8$ & $4.7 \pm 0.9$ \\
\hline
\end{tabular}

Three biochemical parameters (plasma glucose, total protein and cholesterol) were evaluated following inclusion of the vegetables in chickens' diet as shown in table 4 below. The findings showed significant decrease in the level of plasma glucose ( $<<0.001)$ in G1, G2, G3 G4 and G5. For the G0 the levels of plasma glucose remain almost the same throughout the experiment. Pronounced decrease was observed in G2 to G4. For the plasma total protein, the level changed insignificantly $(\mathrm{p}>0.05)$ in almost all groups. There was significant $(\mathrm{p}<0.01)$ decrease in plasma cholesterol levels in all groups except G0. For the G0 the level of plasma cholesterol remained the same throughout the experiment. 
Table 4. Biochemical parameters following inclusion of the selected vegetables

\begin{tabular}{|c|c|c|c|c|c|c|}
\hline \multicolumn{7}{|c|}{ Number of days on experiment } \\
\hline Parameters & Groups & $\mathbf{0}$ & 7 & 14 & 21 & 28 \\
\hline \multirow[t]{6}{*}{ Glucose (mg/dL) } & G0 & $246.7 \pm 15.7$ & $268.9 \pm 31.1$ & $229.0 \pm 15.4$ & $236.9 \pm 20.6$ & $275.0 \pm 159.6$ \\
\hline & G1 & $258.4 \pm 25.4$ & $228.0 \pm 24.2$ & $177.7 \pm 18.7$ & $151.7 \pm 13.0$ & $138.0 \pm 11.2$ \\
\hline & G2 & $306.2 \pm 12.8$ & $282.3 \pm 26.1$ & $148.7 \pm 18.6$ & $146.4 \pm 31.6$ & $98.9 \pm 25.2$ \\
\hline & G3 & $287.9 \pm 21.7$ & $282.8 \pm 27.3$ & $176.8 \pm 10.9$ & $174.0 \pm 33.5$ & $121.8 \pm 56.4$ \\
\hline & G4 & $352.1 \pm 24.0$ & $215.2 \pm 24.5$ & $219.6 \pm 30.4$ & $204.0 \pm 28.0$ & $68.2 \pm 18.2$ \\
\hline & G5 & $226.4 \pm 21.9$ & $307.4 \pm 24.0$ & $141.7 \pm 12.4$ & $203.1 \pm 31.4$ & $171.3 \pm 17.1$ \\
\hline \multirow[t]{6}{*}{ Total protein $(\mathrm{g} / \mathrm{dL})$} & G0 & $4.15 \pm 0.5$ & $4.29 \pm 0.5$ & $4.81 \pm 0.6$ & $3.81 \pm 1.4$ & $4.43 \pm 1.5$ \\
\hline & G1 & $3.67 \pm 0.6$ & $4.93 \pm 0.6$ & $4.84 \pm 0.2$ & $4.47 \pm 0.2$ & $4.46 \pm 0.5$ \\
\hline & G2 & $3.23 \pm 0.5$ & $4.03 \pm 0.4$ & $4.15 \pm 0.6$ & $4.61 \pm 0.4$ & $4.64 \pm 0.8$ \\
\hline & G3 & $4.15 \pm 0.5$ & $5.09 \pm 1.0$ & $2.81 \pm 0.3$ & $2.98 \pm 0.9$ & $4.43 \pm 2.3$ \\
\hline & G4 & $3.75 \pm 0.3$ & $4.22 \pm 0.4$ & $3.37 \pm 0.5$ & $3.16 \pm 0.0$ & $4.15 \pm 0.4$ \\
\hline & G5 & $3.91 \pm 0.3$ & $3.95 \pm 0.3$ & $3.36 \pm 0.1$ & $3.26 \pm 0.1$ & $3.20 \pm 0.2$ \\
\hline \multirow[t]{6}{*}{ Total cholesterol (mg/dL) } & G0 & $149.1 \pm 21.1$ & $133.6 \pm 16.6$ & $102.2 \pm 16.4$ & $115.5 \pm 9.0$ & $123.2 \pm 40.0$ \\
\hline & G1 & $303.6 \pm 38.1$ & $205.5 \pm 18.7$ & $161.7 \pm 12.2$ & $151.7 \pm 10.1$ & $95.4 \pm 8.7$ \\
\hline & G2 & $173.0 \pm 20.3$ & $141.4 \pm 6.8$ & $100.6 \pm 21.0$ & $104.1 \pm 9.4$ & $87.7 \pm 10.5$ \\
\hline & G3 & $341.7 \pm 21.6$ & $190.9 \pm 24.8$ & $161.7 \pm 22.2$ & $127.2 \pm 22.4$ & $107.3 \pm 17.6$ \\
\hline & G4 & $199.2 \pm 52.3$ & $164.5 \pm 36.1$ & $144.5 \pm 16.2$ & $113.8 \pm 16.6$ & $102.2 \pm 15.2$ \\
\hline & G5 & $197.3 \pm 33.3$ & $191.8 \pm 14.0$ & $174.0 \pm 14.1$ & $130.5 \pm 10.4$ & $105.4 \pm 9.9$ \\
\hline
\end{tabular}




\section{Discussion}

The current study assessed the effect of selected botanicals on the body weight, hematological and biochemical parameters in broiler chickens. Following inclusion of sweet potato leaves, roselle and beetroot in chicken feeds, no death or any sign of toxicity was observed throughout the experiment. Feed intake of chickens was observed to range from 90 to 130 gm per cage per day. For the G0, G1, G2, and G5 the feed intake was observed to slightly increase from 125 to 150 gm per day per cage while for, G3 and G4, feed intake was observed to decrease to approximately $90 \mathrm{gm} /$ day. The decreased feed intake in the later three groups could be due to unpleasant taste of the vegetables in feed rations. The increased feed intake concur with a study done by (Bukenya, 2011) who reported the improved appetite of children following intake of roselle juice. A study done by Olubobokun et al., 2013 reported different findings that sweet potato leaves contain Protease inhibitor-2 which is claimed to reduce appetite and food intake, thus stimulate the satiety hormone cholecystokinin (CCK). The CCK hormone stimulates enzyme secretion and delays gastric emptying, creating a feeling of fullness leading to feelings of satiety in animals Beglinger et al., (2001).

Body weight was observed to increase significantly ( $\mathrm{p}<0.001)$ in the control group $(\mathrm{G} 0)$. There was significant decrease $(\mathrm{p}<0.05)$ in the body weigh in all experimental groups as compared to G0 and the group which was given sweet potato leaves in their ration (G1). This is because sweet potato leaves have low fiber and high crude protein content as compared to roselle and beetroot (Ishida et al., 2000) Significant reduction of body weight was observed in G3, G4 and G5. Roselle and beetroot are more fibrous, high in water content, low amounts of protein and calories (Coyle, 2017).

Significant increase in all hematological parameters was observed regardless the type of vegetable given to chickens. The marked increased levels of PCV and $\mathrm{Hb}$ in G1, G4 and G5 could be due to high content of $\beta$-carotene, ascorbic acid and iron in these plants as iron is a major component of hemoglobin in the RBC and its absorption in the gut is facilitated by the ascorbic acid. Similar findings were reported by Unigwe et al., (2016) who reported the increase in PCV, RBC, WBC, and $\mathrm{Hb}$ of broilers fed diets that contained graded levels of sweet potato leaves particularly as the level increased from 5\% to $10 \%$. Study done by (Falade et al., 2005) reported the use of $H$. Sabdariffa (roselle) as an alternative source of iron for the treatment of anaemia. Normal red cell production requires diet containing protein, iron, copper, vitamin $\mathrm{B}_{2}, \mathrm{~B}_{6}, \mathrm{~B}_{12}$ and folic acid (Nyaulingo, 2013). The study done by Jaiswal et al., (2014) reported that administration of $200 \mathrm{mg} / \mathrm{kg}$ beetroot extract to phenyl hydrazine-induced anemic rats significantly increased $(p<0.01)$ the number of RBCs as well as hemoglobin concentration when compared to the untreated group. Beetroot was found to be rich in folic acid, ascorbic acid, iron, vitamin and minerals which are most likely active ingredients responsible for its haematinic effects. Ipomoea batata leaves are also known to increase RBC production from the haemopoietic tissues such as the liver and bone marrow (Koury and Ponka, 2004). This is due to the abundant folic acid which is in the leaves, which is needed for the growth and development of RBC. Findings from another study done by Indhumathi and Kannikaparameswari (2012) recorded significant increase in the 
hematological parameters such as $\mathrm{PCV}, \mathrm{Hb}, \mathrm{RBCs}$ counts and total lymphocyte count following oral administration of Beta vulgaris methanolic extract.

Blood glucose and cholesterol significantly decreased $(\mathrm{p}<0.05)$ in all experimental groups. Similar findings were reported by Wootton-Beard, Brandt, Fell, Warner, and Ryan (2014) that sweet potato and roselle has post-prandial effect on glucose and insulin concentrations by inhibiting $\alpha$-glucosidase and $\alpha$-amylase thus cause delay of carbohydrate digestion to absorbable monosaccharide. Study done by Ludvik et al., (2008) showed that the blood glucose lowering effect of white skinned sweet potato in type 2 diabetic patients has been linked to an increase in blood levels of adiponectin; an adipocyte hormone that serves as an important modifier of insulin metabolism. Also, H. sabdariffa extract was shown to be a potent pancreatic $\alpha$-amylase inhibitor Adisakwattana et al., 2012. Similar results were found for hibiscus acid (hibiscus-type (2S, 3R)-hydroxycitric acid lactone) (Yamada et al., 2007), which inhibited pancreatic $\alpha$-amylase and intestinal $\alpha$-glucosidase enzyme (Hansawasdi et al., 2000). The extracts from $H$. sabdariffa were able to decrease low-density lipoprotein cholesterol (LDL-c), triglycerides (TAG), total cholesterol (TC) and lipid peroxidation in vivo (Ochani and D'Mello 2009). H. sabdariffa is also reported to be used as anti-cancer, antioxidants and anti-inflammatory. This is due to presence of anthocyannins, flavonoids and polyphenols which contribute to the cardio-protective actions.

In conclusion, the three plants i.e. I. batata (sweet potatoes) leaves, H. Sabdariffa (roselle) calyces and B. vulgaris (beetroot) have showed increasing effect on the tested hematological parameters and also lowering biochemical parameters such as plasma glucose and cholesterol The increased haematological parameters and lowering effect of blood glucose and cholesterol are interesting findings suggesting that the studied vegetables can be recommended for management of conditions such as obesity, diabetes mellitus, hyperlipidemia and cardiovascular diseases (atherosclerosis and coronary disease) in other animals including human beings. Further studies to assess how the three mentioned vegetables work in the animal body are recommended.

\section{Ethical approval}

This research was conducted in adherence with the Sokoine University of Agriculture (SUA) Code of Conduct for Research Ethics and approved by the Ethical Clearance Committee of the College of Veterinary Medicine and Biomedical Sciences.

\section{Acknowledgement}

The authors would like to thank Sokoine University of Agriculture for contributing to the success of this work.

\section{Conflict of Interest}

No conflict of interest associated with this work. 


\section{References}

Adisakwattana, S., Ruengsamran, T., Kampa, P., \& Sompong, W. (2012). In vitro inhibitory effects of plant-based foods and their combinations on intestinal $\alpha$-glucosidase and pancreatic $\alpha$-amylase. BMC Complementary and Alternative Medicine, 12(1), 110. https://doi.org/10.1186/1472-6882-12-110

Antia, B., Okokon, J., Nwidu, L., \& Jackson, C. (2006). Effect of subchronic administration of ethanolic stembark extract of Mammea africana Sabine on haematological and biochemical parameters of rats. African Journal of Biomedical Research, 9(2). https://doi.org/10.4314/ajbr.v9i2.48894

Beglinger, C., Degen, L., Matzinger, D., D'Amato, M., \& Drewe, J. R. (2001). Loxiglumide, a CCK-A receptor antagonist, stimulates calorie intake and hunger feelings in humans. American Journal of Physiology-Regulatory, Integrative and Comparative Physiology, 280(4), R1149-R1154. https://doi.org/10.1152/ajpregu.2001.280.4.R1149

Bukenya, R. (2011). Effect of consumption of roselle juice on haemoglobin concentration, appetite and vitamin c saturation in children aged below 24 months. Sokoine University of Agriculture.

Chang, Y. C., Huang, K. X., Huang, A. C., Ho, Y. C., \& Wang, C. J. (2006). Hibiscus anthocyanins-rich extract inhibited LDL oxidation and oxLDL-mediated macrophages apoptosis. Food and chemical Toxicology, 44(7), 1015-1023. https://doi.org/10.1016/j.fct.2005.12.006

Crawford, R. S., Kirk, E. A., Rosenfeld, M. E., LeBoeuf, R. C., \& Chait, A. (1998). Dietary antioxidants inhibit development of fatty streak lesions in the LDL receptor-deficient mouse. Arteriosclerosis, Thrombosis, and Vascular Biology, 18(9), 1506-1513. https://doi.org/10.1161/01.ATV.18.9.1506

Elagib, H., \& Ahmed, A. (2011). Comparative study on haematological values of blood of indigenous chickens in Sudan. Asian Journal of Poultry Science, 5(1), 41-45. https://doi.org/10.3923/ajpsaj.2011.41.45

Etim, N., Williams, M. E., Akpabio, U., \& Offiong, E. E. (2014). Haematological parameters and factors affecting their values. Agricultural Science, 2(1), 37-47. https://doi.org/10.12735/as.v2i1p37

Falade, O., Otemuyiwa, I., Oladipo, A., Oyedapo, O., Akinpelu, B., \& Adewusi, S. (2005). The chemical composition and membrane stability activity of some herbs used in local therapy for anemia. Journal of Ethnopharmacology, 102(1), 15-22. https://doi.org/10.1016/j.jep.2005.04.034

FAOSTAT. (2006). FAO database.

Farombi, E., \& Ige, O. (2007). Hypolipidemic and antioxidant effects of ethanolic extract from dried calyx of Hibiscus sabdariffa in alloxan-induced diabetic rats. Fundamental \& Clinical Pharmacology, 21(6), 601-609. https://doi.org/10.1111/j.1472-8206.2007.00525.x 
Gilchrist, M., Winyard, P. G., Fulford, J., Anning, C., Shore, A. C., \& Benjamin, N. (2014). Dietary nitrate supplementation improves reaction time in type 2 diabetes: development and application of a novel nitrate-depleted beetroot juice placebo. Nitric Oxide, 40, 67-74. https://doi.org/10.1016/j.niox.2014.05.003

Gosain, S., Ircchiaya, R., Sharma, P. C., Thareja, S., Kalra, A., Deep, A., \& Bhardwaj, T. R. (2010). Hypolipidemic effect of ethanolic extract from the leaves of Hibiscus sabdariffa L. in hyperlipidemic rats. Acta Poloniae Pharmaceutica, 67(2), 179-184.

Graczyk, S., Pliszczak-Król, A., Kotoński, B., Wilczek, J., \& Chmielak, Z. (2003). Examinations of hematological and metabolic changes mechanisms of acute stress in turkeys. Veterinary Medicine, 6(1), 05.

Guyton, J., \& Klemp, K. (1993). Transitional features in human atherosclerosis. Intimal thickening, cholesterol clefts, and cell loss in human aortic fatty streaks. The American Journal of Pathology, 143(5), 1444.

Hansawasdi, C., Kawabata, J., \& Kasai, T. (2000). $\alpha$-Amylase inhibitors from roselle (Hibiscus sabdariffa Linn.) tea. Bioscience, Biotechnology, and Biochemistry, 64(5), 1041-1043. https://doi.org/10.1271/bbb.64.1041

Hobbs, D. A., Goulding, M. G., Nguyen, A., Malaver, T., Walker, C. F., George, T. W., \& Lovegrove, J. A. (2013). Acute Ingestion of Beetroot Bread Increases Endothelium-Independent Vasodilation and Lowers Diastolic Blood Pressure in Healthy Men: A Randomized Controlled Trial-4. The Journal of Nutrition, 143(9), 1399-1405. https://doi.org/10.3945/jn.113.175778

Hopkins, A. L., Lamm, M. G., Funk, J. L., \& Ritenbaugh, C. (2013). Hibiscus sabdariffa L. in the treatment of hypertension and hyperlipidemia: a comprehensive review of animal and human studies. Fitoterapia, 85, 84-94. https://doi.org/10.1016/j.fitote.2013.01.003

Indhumathi, T., \& Kannikaparameswari, K. (2012). Hematopoietic study of the methanolic root extract of Beta vulgaris on albino rats-an in vivo study. International Journal of Pharmacology and Biological Sciences, 3(4), 1005-1015.

Ishida, H., Suzuno, H., Sugiyama, N., Innami, S., Tadokoro, T., \& Maekawa, A. (2000). Nutritive evaluation on chemical components of leaves, stalks and stems of sweet potatoes (Ipomoea batatas poir). Food Chemistry, 68(3), 359-367. https://doi.org/10.1016/S0308-8146(99)00206-X

Jaiswal, A., Ganeshpurkar, A., Awasthi, A., Bansal, D., Dubey, N., Singh, A. K., \& Naved, T. (2014). Protective Effects of Beetroot Extract against Phenyl Hydrazine Induced Anemia in Rats. Pharmacognosy Journal, 6(5), 1-4. https://doi.org/10.5530/pj.2014.5.1

Jajja, A., Sutyarjoko, A., Lara, J., Rennie, K., Brandt, K., Qadir, O., \& Siervo, M. (2014). Beetroot supplementation lowers daily systolic blood pressure in older, overweight subjects. Nutrition Research, 34(10), 868-875. https://doi.org/10.1016/j.nutres.2014.09.007 
Karyeija, R., Gibson, R., \& Valkonen, J. (1998). The significance of sweet potato feathery mottle virus in subsistence sweet potato production in Africa. Plant Disease, 82(1), 4-15. https://doi.org/10.1094/PDIS.1998.82.1.4

Koury, M. J., \& Ponka, P. (2004). New insights into erythropoiesis: the roles of folate, vitamin B12, and iron. Annual Review of Nutrition, 24, 105-131. https://doi.org/10.1146/annurev.nutr.24.012003.132306

Lechner, J. F., Wang, L. S., Rocha, C. M., Larue, B., Henry, C., McIntyre, C. M., \& Stoner, G. D. (2010). Drinking water with red beetroot food color antagonizes esophageal carcinogenesis in N-nitrosomethylbenzylamine-treated rats. Journal of Medicinal Food, 13(3), 733-739. https://doi.org/10.1089/jmf.2008.0280

Lidder, S., \& Webb, A. J. (2013). Vascular effects of dietary nitrate (as found in green leafy vegetables and beetroot) via the nitrate-nitrite-nitric oxide pathway. British Journal of Clinical Pharmacology, 75(3), 677-696. https://doi.org/10.1111/j.1365-2125.2012.04420.x

Ludvik, B., Hanefeld, M., \& Pacini, G. (2008). Improved metabolic control by Ipomoea batatas (Caiapo) is associated with increased adiponectin and decreased fibrinogen levels in type 2 diabetic subjects. Diabetes, Obesity and Metabolism, 10(7), 586-592. https://doi.org/10.1111/j.1463-1326.2007.00752.x

Lundberg, J. O., Weitzberg, E., \& Gladwin, M. T. (2008). The nitrate-nitrite-nitric oxide pathway in physiology and therapeutics. Nature reviews Drug discovery, 7(2), 156. https://doi.org/10.1038/nrd2466

Milind, P., \& Monica (2015). Sweet potato as a super food. International Journal of Research in Ayuverda Pharmacology, 6(4), 557-562. https://doi.org/10.7897/2277-4343.064104

Mohanraj, R., \& Sivasankar, S. (2014). Sweet Potato (Ipomoea batatas [L.] Lam)-A valuable medicinal food: A review. Journal of Medicinal Food, 17(7), 733-741. https://doi.org/10.1089/jmf.2013.2818

Ninfali, P., \& Angelino, D. (2013). Nutritional and functional potential of Beta vulgaris cicla and rubra. Fitoterapia, 89, 188-199. https://doi.org/10.1016/j.fitote.2013.06.004

Nkumah, O. C. (2015). Phytochemical analysis and medicinal uses of Hibiscus sabdariffa. International Journal of Herbal Medicine; 2, 16-19.

Nyaulingo, J. M. (2013). Effect of different management systems on haematological parameters in layer chickens. Sokoine University of Agriculture.

Ochani, P. C., \& D'Mello, P. (2009). Antioxidant and antihyperlipidemic activity of Hibiscus sabdariffa Linn. leaves and calyces extracts in rats. Indian Journal of Experimental Biology, 47, 276-282.

Olubobokun, T. H., Aluko, E. O., Bond, A. U., \& Atang, D. E. (2013). Ipomoea batatas L. extract reduces food intake, fasting blood glucose levels and body weight. European Journal of Medicinal Plants, 3(4), 530. https://doi.org/10.9734/EJMP/2013/4673 
Onyenekwe, P., Ajani, E., Ameh, D., \& Gamaniel, K. (1999). Antihypertensive effect of roselle (Hibiscus sabdariffa) calyx infusion in spontaneously hypertensive rats and a comparison of its toxicity with that in Wistar rats. Cell Biochemistry and Function: Cellular biochemistry and its modulation by active agents or disease, 17(3), 199-206. https://doi.org/10.1002/(SICI)1099-0844(199909)17:3<199::AID-CBF829>3.0.CO;2-2

Osime, E., Ediale, G., Omoti, C., \& Famodu, A. (2008). Effect of sweetpotato leaf (Ipomoea batatas) extract on some haematological parameters using rabbits. Journal of Medicine and Biomedical Research, 7(1-2). https://doi.org/10.4314/jmbr.v7i1-2.44540

Scaramuzzi, F. (1986). Sweet potato (Ipomoea batatas Poir.) Crops I (pp. 455-461): Springer. https://doi.org/10.1007/978-3-642-61625-9_25

Talebi, A., Asri-Rezaei, S., Rozeh-Chai, R., \& Sahraei, R. (2005). Comparative studies on haematological values of broiler strains (Ross, Cobb, Arbor-acres and Arian). International Journal of Poultry Science, 4(80), 573-579. https://doi.org/10.3923/ijps.2005.573.579

Vecerek, V., Strakova, E., Suchy, P., \& Voslarova, E. (2002). Influence of high environmental temperature on production and haematological and biochemical indexes in broiler chickens. Czech Journal of Animal Science, 47(5), 176-182.

Wang, C. J., Wang, J. M., Lin, W. L., Chu, C. Y., Chou, F. P., \& Tseng, T. H. (2000). Protective effect of Hibiscus anthocyanins against tert-butyl hydroperoxide-induced hepatic toxicity in rats. Food and Chemical Toxicology, 38(5), 411-416. https://doi.org/10.1016/S0278-6915(00)00011-9

Wootton-Beard, P. C., Brandt, K., Fell, D., Warner, S., \& Ryan, L. (2014). Effects of a beetroot juice with high neobetanin content on the early-phase insulin response in healthy volunteers. Journal of Nutritional Science, 3. https://doi.org/10.1017/jns.2014.7

Yang, D. J., Chang, Y. Y., Hsu, C. L., Liu, C. W., Wang, Y., \& Chen, Y. C. (2010). Protective effect of a litchi (Litchi chinensis Sonn.)-flower-water-extract on cardiovascular health in a high-fat/cholesterol-dietary hamsters. Food Chemistry, 119(4), 1457-1464. https://doi.org/10.1016/j.foodchem.2009.09.027

Yang, M. Y., Peng, C. H., Chan, K. C., Yang, Y. S., Huang, C. N., \& Wang, C. J. (2009). The hypolipidemic effect of Hibiscus sabdariffa polyphenols via inhibiting lipogenesis and promoting hepatic lipid clearance. Journal of Agricultural and Food Chemistry, 58(2), 850-859. https://doi.org/10.1021/jf903209w

\section{Copyright Disclaimer}

Copyright for this article is retained by the author(s), with first publication rights granted to the journal.

This is an open-access article distributed under the terms and conditions of the Creative Commons Attribution license (http://creativecommons.org/licenses/by/3.0/). 